\title{
MODELLING OF MULTI-LAYER MATERIALS CUTTING
}

\author{
Wojciech ZĘBALA
}

\begin{abstract}
S u m mary
The paper presents some aspects of modelling of multi-layer materials cutting process. Numerical calculation with the finite element method (Lagrangian equations) were performed for the decohesion process simulation of the example workpieces (machined with one tool wedge) consisted of two and three layers with different mechanical properties. Results of calculation in the form of colour maps of temperature and plastic strain fields distributions in the cutting zone are presented. An example course in time of the main cutting force components, during wedge tool passage through the different layers of the cutting material, is presented.
\end{abstract}

Keywords: modelling, cutting, multi-layer materials

Modelowanie skrawania materiałów wielowarstwowych

Streszczenie

W pracy omówiono wybrane zagadnienia modelowania procesu skrawania materiałów wielowarstwowych. Obliczenia numeryczne metodą elementów skończonych (równania Lagrange’a) prowadzono w celu symulacji procesu dekohezji modelowych materiałów obrabianych. Materiały składają się z dwóch lub trzech warstw o różnych właściwościach mechanicznych. Obróbkę skrawaniem prowadzono za pomocą jednego ostrza narzędzia. Określono rozkłady wartości temperatury i odkształcenia plastycznego w strefie skrawania. Przedstawiono przykłady zmiany wartości składowych całkowitej siły skrawania podczas przejścia ostrza narzędzia między różnymi warstwami skrawanego materiału.

Słowa kluczowe: modelowanie, skrawanie, materiały wielowarstwowe

\section{Introduction}

Application of computer methods for designing of technological processes is necessary to fulfil today's high demands concerning accuracy and efficiency of the manufacturing process of machine parts, by removing layers of material from the workpiece with a cutting tool. The construction of machining simulation models enables speedy visualization of chip creation process in a wide range of machining parameters [1-3].

Address: Wojciech ZĘBALA, D.Sc. Eng., Cracow University of Technology, Production Engineering Institute, al Jana Pawła II 37, 31-864 Kraków, Poland, e-mail: zebala@mech.pk.edu.pl 
Multi-layer material (called a composite) is a material with inhomogeneous structure, combined from two or more components with different properties. One of the constituent materials is a warp (matrix) bonding the composite into a whole and giving it hardness, elasticity and compression resistance. The other component of the composite is a structural material responsible for reinforcement of the composite by forming its other properties. In general, the role of the warp is to protect the reinforcing material, transfer external stresses onto it, and provide the required shape to the composite part produced, while function of the reinforcing material is reduced to secure high mechanical properties for the composite and reinforce the warp in selective directions [4]. Properties of the composite depend on the physical properties of the warp and those of the reinforcing material, form of a reinforcement (fibres, particles) and relative contents of the warp $\left(\mathrm{V}_{\mathrm{o}}\right)$ and the reinforcement $\left(\mathrm{V}_{\mathrm{w}}\right)$ formulated as volumetric fractions $\left(\mathrm{V}_{0}+\mathrm{V}_{\mathrm{w}}=100 \%\right)$.

Composite materials can be divided into the following groups [5]:

- Structural composites - where continuous structures of the structural components occur - layers (e.g., plywood), rods (e.g., reinforced concrete) or regular three-dimensional structures, e.g., structures resembling a honeycomb.

- Laminates - which are composed of the fibres sealed into the binders - depending on the fibre order we can distinguish composite bands - fibres arranged in one direction - composite mats in two perpendicular directions - or composites with fibres arranged at random.

- Micro-composites and nano-composites - in which regular structure of two or more components is already arranged on the hyper molecular level - e.g., wood is a kind of the micro-composite, composed of the cellulose fibres twisted in bundles, "glued" by a lignin.

- Structural alloys - which are a kind of metal alloys, metals with nonmetals, polymers with polymers and polymers with metals and non-metals with very regular microstructure, e.g., duralumin.

Properties of the composite with long and orderly fibres are definitely anisotropic. Long fibres can be unidirectional (all fibres parallel to each other) or weaved into a woven fabric form (,,preform" technique). Unidirectional location of fibres provides the highest mechanical properties to the composite.

Growing interest in composite materials - including mainly the fibrous composites - and the specificity of its structure cause the need to develop the rational methods for their machining. Composites are characterized by the nonhomogeneous structure and anisotropy and are the materials with highly abrasive properties, which is the cause that machining involves many difficulties [5, 6].

In the case of precision cutting of different construction materials, like steel or other metal alloys we should also consider multi-layer workpieces of "composite" type [7-9]. Figure 1-2 show the differences between macro and micro scale of cutting. 
a)

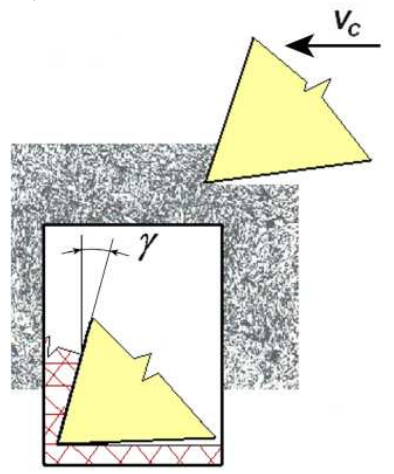

b)

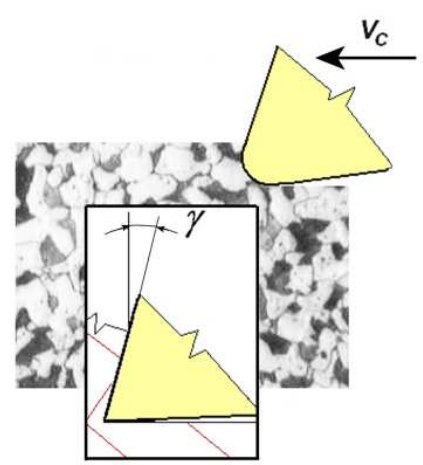

Fig. 1. Relation between undeformed chip thickness $\mathrm{h}$ and grain size: a) conventional size cutting, b) micro-cutting

During micro-cutting a chip is formed basing on the division of a single grain (Fig. 1b) and the formed chip experiences a negative rake angle of high modulus, Fig. 2b. In the conventional size cutting a cutting edge can be assumed as almost perfectly sharp and the actual rake angle corresponds to the nominal one, Fig. 1a, 2a.

a)

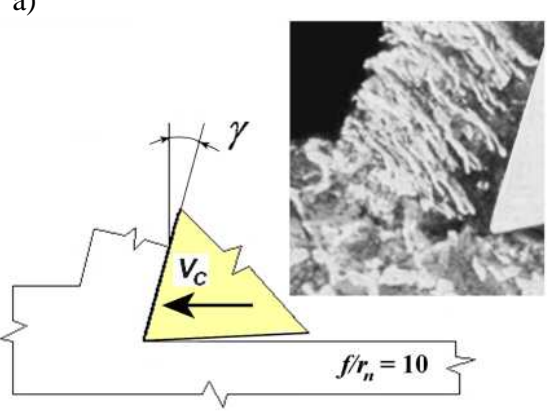

b)

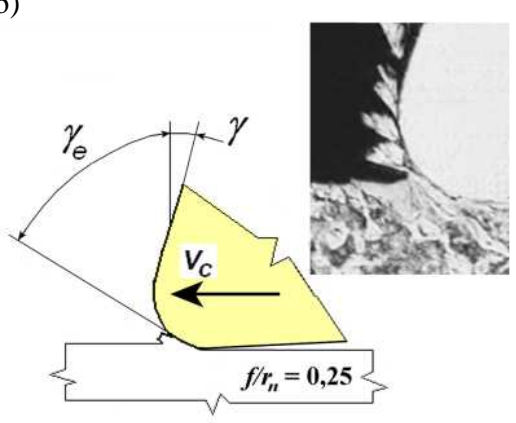

Fig. 2. Relation between undeformed chip thickness $h$ and cutting edge radius $r_{n}$ : a) conventional size cutting, b) micro-cutting

The microstructure has a very strong influence on the chip formation process [7]. Figure 3 shows the $\mathrm{C} 45$ steel with a relatively large grain structure during decohesion process for different undeformed chip thickness, which can be varied substantially through heat treatment and throughout the workpiece. The average ferrite grain size is about $10 \mu \mathrm{m}$ while pearlite grains can exceed $100 \mu \mathrm{m}$. 

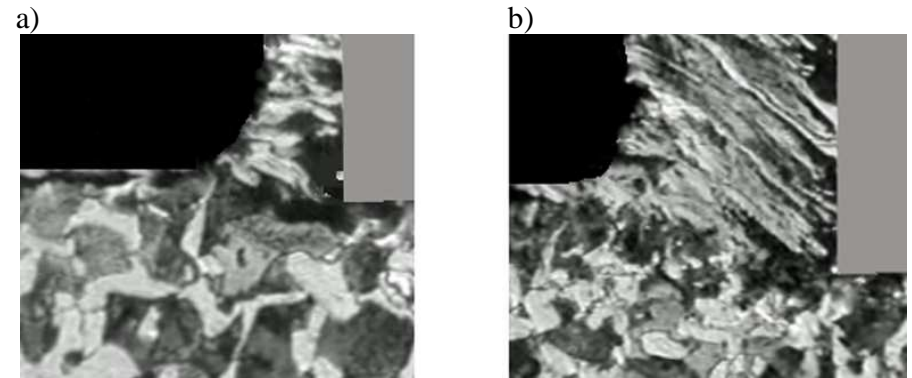

Fig. 3. Optical images of the $\mathrm{C} 45$ steel microstructure during decohesion process for different undeformed chip thickness: a) $h=0,02 \mathrm{~mm}$, b) $h=$ $=0,05 \mathrm{~mm}$; larger pearlite grains (grey) and smaller ferrite grains (white)

Figure 4a presents a FE model, showing the micro-scale cutting across two different materials: bigger pearlite (A) and smaller ferrite (B) [8]. The general FE model is based on a number of basic assumptions. The cutting tool is assumed to be sharp even at such a small scale with no BUE. The material properties of $\mathrm{A}$ and $\mathrm{B}$ are meant to be rough approximations of a pearlite and ferrite microstructure respectively.

a)

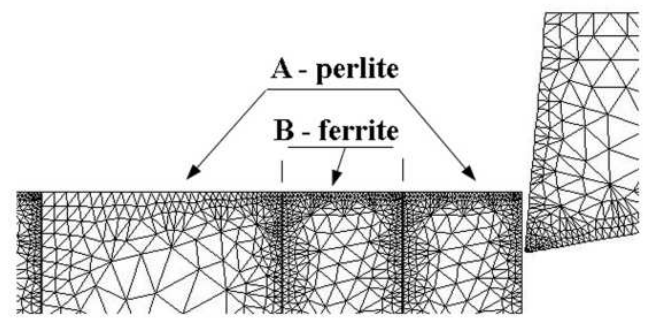

b)

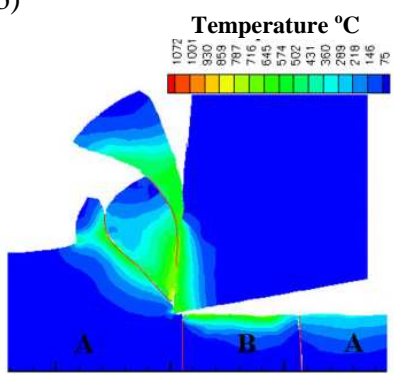

Fig. 4. Chip formation during micro-cutting: a) FE model showing the micro-scale cutting across two different materials (A - pearlite grain, B - ferrite grain), b) temperature distribution in the cutting zone

Basing on a numerical calculation a chip shape and temperature distribution in the micro-cutting zone were achieved, Fig. 4b. Cutting speed and feed were respectively: $300 \mathrm{~m} / \mathrm{min}$ and $0,005 \mathrm{~mm}$.

\section{Modelling and simulation}

Modelling researches embraced the working out of an analytical model of multi-layer materials decohesion process in condition of high speed shaping. Within the framework of numerical calculations a material strain analysis was taken. Model took into consideration the physical properties of the pair: tool 
wedge-cutting material. The achieved distributions of temperature, stress and strain fields permit the virtual model determination of the decohesion process of specific composite materials. Lagrangian finite element method was used to simulation of the decohesion process [10]. Equation 1 presents the constitutive model by which the material will be governed.

$$
\sigma\left(\varepsilon^{p}, \dot{\varepsilon}, T\right)=g\left(\varepsilon^{p}\right) * \Gamma(\dot{\varepsilon}) * \Theta(T)
$$

where $g\left(\varepsilon^{p}\right)$ is strain hardening, $\Gamma(\dot{\varepsilon})$ is strain rate sensitivity and $\Theta(T)$ is thermal softening.

The composite material could crack during acting of the tool edge on it. The model of crack propagation in material consists of a curve fit (up to a 5-order polynomial) to a Strain to Failure vs. Temperature graph. The following equation (2) contains coefficients defining the strain to failure function.

$$
\varepsilon_{f_{0}}^{p}=d_{0}+d_{1} T+d_{2} T^{2}+d_{3} T^{3}+d_{4} T^{4}+d_{5} T^{5}
$$

The results of an example computer simulation of decohesion process of two-ply workpiece (composite consists of horizontal layers) in the separate phases, in the form of temperature field distribution are presented in Fig. 5-7. Layer 2 is about three times harder than layer 1, see Table 1. Cutting speed $v_{c}=300 \mathrm{~m} / \mathrm{min}$.

Table 1. Properties of two-ply workpiece

\begin{tabular}{|c|c|c|}
\hline Properties & Layer 1 & Layer 2 \\
\hline Yield strength & $220 \mathrm{MPa}$ & $612 \mathrm{MPa}$ \\
\hline Hardness & $110 \mathrm{BHN}$ & $305 \mathrm{BHN}$ \\
\hline
\end{tabular}

a)

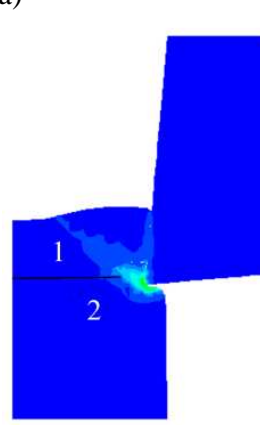

b)

Temperature ${ }^{\circ} \mathrm{C}$

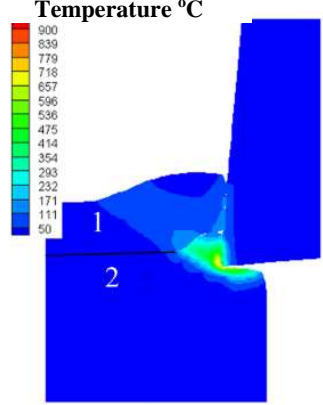

$1 \mathrm{~mm}$ c)

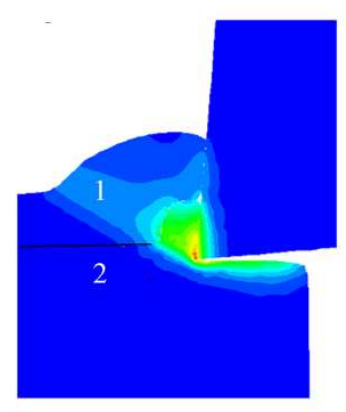

Fig. 5. Model of decohesion zone - successive phases of decohesion process (a) $\div$ (c) 
a)

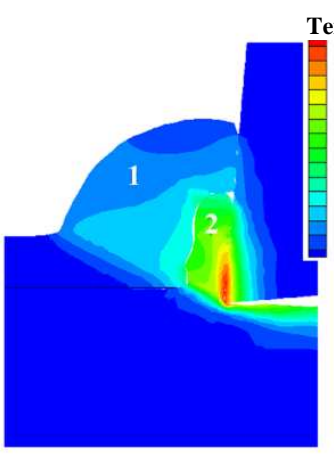

b)

emperature ${ }^{\circ} \mathrm{C}$

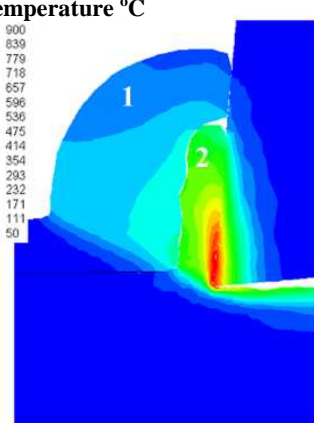

$1 \mathrm{~mm}$ c)

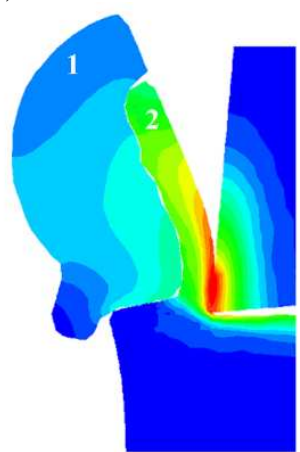

Fig. 6. Model of decohesion zone - successive phases of decohesion process, continuation (a) $\div$ (c)

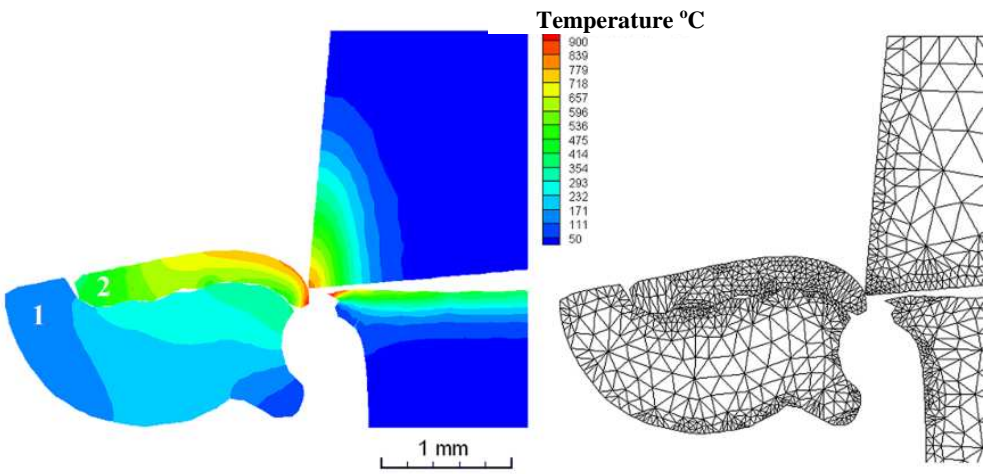

Fig. 7. Model of decohesion zone - the last phase of chip creation: a) temperature field distribution, b) model with finite element net

Calculation values like chip compression ratio, maximum temperature and plastic strain values in the chip body coming from different layers are presented in Table 2. For comparison, Table 2 contains the same values but calculated for homogenous model, built from only one material (as layer 2). Uncut chip thickness was $0,1 \mathrm{~mm}$. The other parameters were the same as for two-ply workpiece.

Table 2. Chip compression ratio, maximum temperature and plastic strain values in the chip body coming from different layers and from homogenous model

\begin{tabular}{|l|c|c|c|}
\hline Chip coming from & $\boldsymbol{\Lambda}_{\boldsymbol{h}}$ & $\boldsymbol{T}_{\boldsymbol{m a x}},{ }^{\mathbf{0}} \mathbf{C}$ & $\boldsymbol{\varepsilon}$ \\
\hline Layer 1st (Upper part of the chip) & 2,25 & 303 & 1,8 \\
\hline Layer 2 ${ }^{\text {nd }}$ (Bottom part of the chip) & 3 & 852 & 5,6 \\
\hline $\begin{array}{l}\text { Homogenous model (properties of } \\
\text { layer 2) }\end{array}$ & 2,1 & 770 & 5,3 \\
\hline
\end{tabular}


The relative high chip compression ratio can be observed. The part of the chip, created from the more strength material (layer 2) possesses a higher chip compression ratio $\left(\Lambda_{h}=3\right)$ than in the case of homogenous model $\left(\Lambda_{h}=2,1\right)$. It results from the additional difficulties of the free chip flow, which is blocked by the upper layer of the two-ply model. The increase of normal force, acting on the rake face increases the friction force in this region, what causes the bigger value of the chip compression ratio and higher temperature in the cutting zone $\left(852^{\circ} \mathrm{C}\right)$ (Fig. 8). The maximum plastic strain is bigger and exists in the bottom part of the chip, close to the cutting edge $(5,6)$ (Fig. 9).

a)

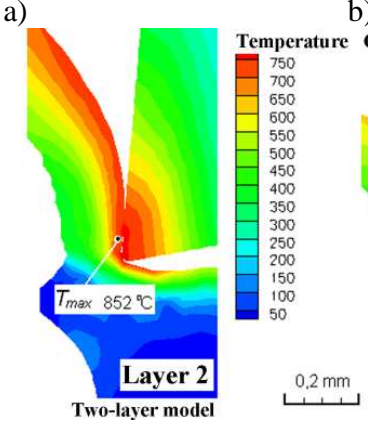

b)

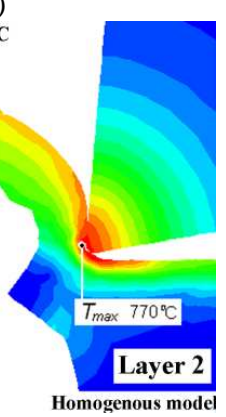

Fig. 8. Temperature field distribution in the workpiece for: a) two-ply model, b) homogenous model

a)

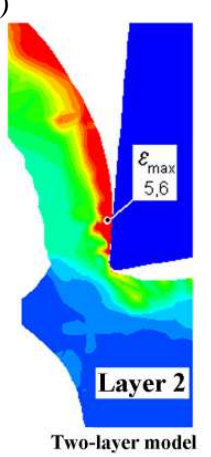

b)

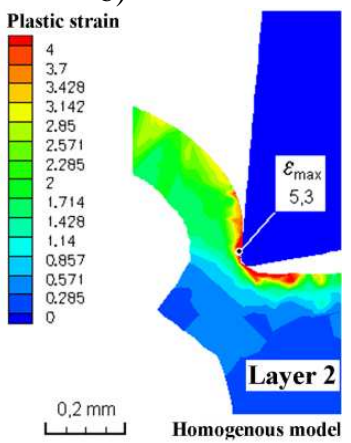

Fig. 9. Plastic strain field distribution in the workpiece for: a) two-ply model, b) homogenous model

The following example in Fig. 10-11 presents the model of decohesion process of composite substance, consisted of three vertical layers made of different materials (Tab. 3). Cutting speed $v_{c}=75 \mathrm{~m} / \mathrm{min}$. The courses in time of main force components $F_{x}$ and $F_{y}$, during process are presented in Fig. 12. 
Table 3. Properties of three-ply workpiece

\begin{tabular}{|l|l|l|l|}
\hline \multicolumn{1}{|c|}{ Properties } & \multicolumn{1}{c|}{ Layer 1 } & \multicolumn{1}{c|}{ Layer 2 } & \multicolumn{1}{c|}{ Layer 3 } \\
\hline Yield strength & $220 \mathrm{MPa}$ & $290 \mathrm{MPa}$ & $240 \mathrm{MPa}$ \\
\hline Hardness & $110 \mathrm{BHN}$ & $205 \mathrm{BHN}$ & $180 \mathrm{BHN}$ \\
\hline
\end{tabular}

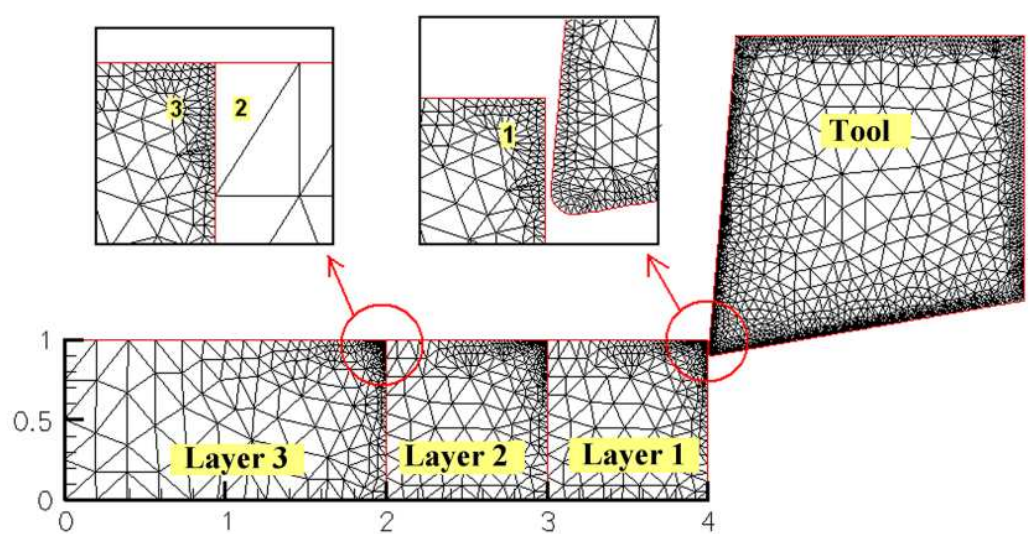

Fig. 10. Model of three-ply decohesion zone (finite element net) - initial phase of decohesion process. Layers are placed perpendicular to the cutting speed vector

a)

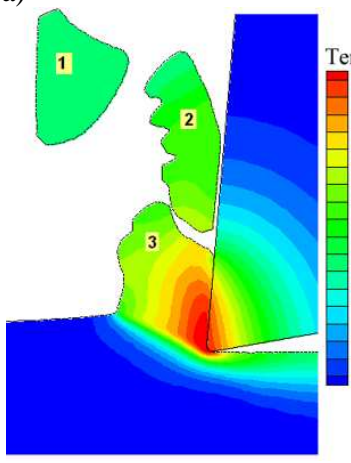

b)

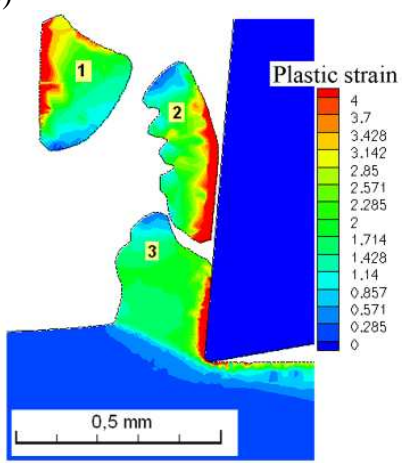

Fig. 11. Model of decohesion zone: a) temperature field distribution, b) plastic strain distribution

The chip after cutting consists of three parts. Cutting forces violently change their values in the moment of the beginning of the successive material cutting. Chip compression ratio, maximum temperature and plastic strain values in the chip body coming from different layers are presented in Table 4. 


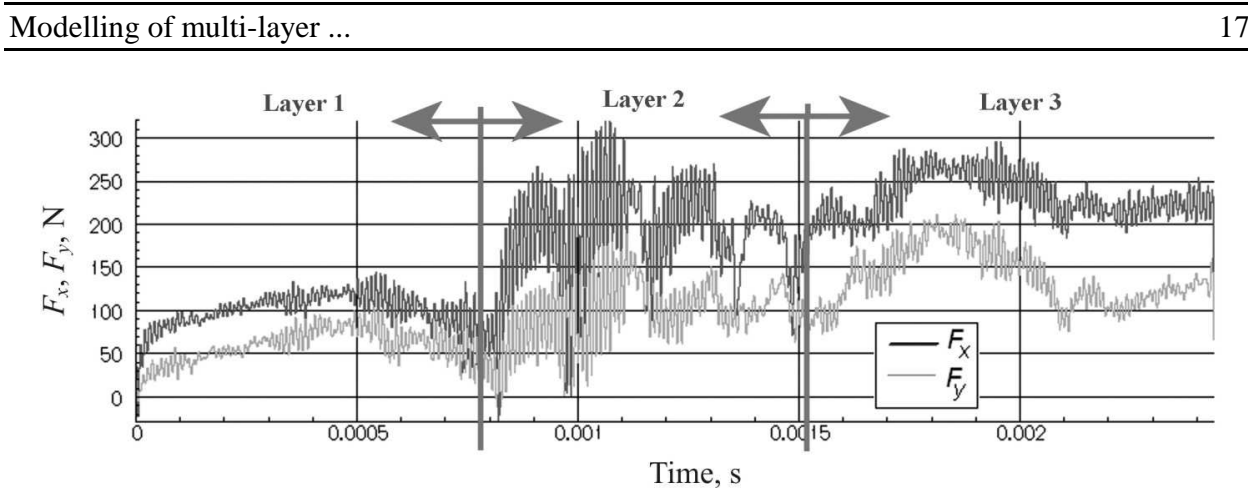

Fig. 12. Course in time of $F_{x}$ and $F_{y}$ main force components during decohesion process

Table 4. Chip compression ratio, maximum temperature and plastic strain values in the chip body coming from different layers

\begin{tabular}{|c|c|c|c|}
\hline Chip coming from & $\boldsymbol{\Lambda}_{\boldsymbol{h}}$ & $\boldsymbol{T}_{\boldsymbol{m a x}},{ }^{\mathbf{0}} \mathbf{C}$ & $\boldsymbol{\varepsilon}$ \\
\hline Layer 1st & 3,25 & 274 & 6,9 \\
\hline Layer 2nd & 2,1 & 410 & 4,1 \\
\hline Layer 3rd & 3,4 & 415 & 6,8 \\
\hline
\end{tabular}

\section{Conclusions}

In the case of composites we have to deal with multi-layer materials. Composites are particularly applied in the sectors such as aircraft, aerospace and automotive industries. Increasing application of these kind of materials causes the necessity of the rational methods of their forming. Modelling researches of the multi-layer workpieces permit the prognosis of the machined material behavior in non-typical conditions. The correct selection of the cutting parameters, in the situation of the cutting of materials with various physical proprieties (e.g. the alloy of aluminum and steel) with one tool is essential from the point of view of the surface quality and tool wear.

\section{References}

[1] J.A. ARSECULARATNE, R.F. FOWLE, P. MATHEW: Prediction of chip flow direction, cutting forces and surface roughness in finish turning. Trans. of ASME, J. Manufacturing Science and Eng., 120(1998), 1-12.

[2] J. LEOPOLD: From macroscopically scale to the microscopically scale in modeling and simulation of machining. Proc. of Inter. Users' Conference „Modeling Technology-Machining Solution”, vol. 4, 1-14. Minneapolis 2008.

[3] W. ZĘBALA: Modeling of cutting process with cooling. Advances in Manufacturing Science and Technology, 32(2008)4, 73-81. 
[4] R. TETI: Machining of composite materials. Ann. of the CIRP, 51(2002)2, 611634.

[5] K. OCZOŚ: Problemy kształtowania ubytkowego kompozytów włóknistych z osnową polimerową i ceramiczną. Mechanik, (2011)1, 5-10.

[6] A. LUECK: Höchste Stabilität durch Langfaserverstärkung. Lange Fasern - kurze Zeiten. Industrie-Anzeiger, 129(2007)17, 34-35.

[7] A. SIMONEAU, E. ELBESTAWI NG, M.A.: Chip formation during micro-scale cutting of a medium carbon steel. Inter. Journal of Machine Tools \& Manufacture, 46(2006), 467-481.

[8] W. ZEBALA: Modelling problems in precision cutting. Proc. of Inter. Conference ITC, Zlin 2007, 1-6.

[9] W. ZEBBALA, M. KOWALCZYK: Some aspects of precision machining and nanotechnology. Proc. of Inter. Conference microCAD, Miszkolc 2007, 191-198.

[10] User's Manual of AdvantEdge v5.6, machining simulation software, Minneapolis 2010.

Received in December 2011 